\title{
Trophic transfer and habitat use of oyster Crassostrea virginica reefs in southwest Florida, identified by stable isotope analysis
}

\author{
Holly A. Abeels ${ }^{1,2}$, Ai Ning Loh ${ }^{1}$, Aswani K. Volety ${ }^{1, *}$ \\ ${ }^{1}$ Florida Gulf Coast University, Fort Myers, Florida 33965, USA \\ ${ }^{2}$ Present address: University of Florida/Institute of Food and Agricultural Sciences, Brevard County Extension Service, \\ Cocoa, Florida 32926, USA
}

\begin{abstract}
Oyster reefs have been identified as essential fish habitat for resident and transient species. Many organisms found on oyster reefs, including shrimp, crabs, and small fishes, find shelter and food on the reef and in turn provide food for transient species that frequent oyster reefs. The objective of this study was to determine trophic transfer on oyster reefs in a subtropical environment using stable isotope compositions. Water, sediment, particulate organic matter, various crustaceans, fishes, as well as oysters were collected at 2 sites in Estero Bay, Florida, during the wet and dry seasons, and processed for $\delta^{13} \mathrm{C}$ and $\delta^{15} \mathrm{~N}$ stable isotope analyses. Differences in freshwater input (salinity) resulted in differences in carbon and nitrogen isotope ratios. Overall, fish and shrimp are secondary consumers, with crabs and oysters as primary consumers, and organic matter sources at the lowest trophic level. Results of the study further demonstrate that reef-resident organisms consume other organisms found on the reef and/or primary producers and detrital organic matter on the reef. Transient fish species come to the reef to feed on the reefresident species.
\end{abstract}

KEY WORDS: Oysters - Crassostrea virginica · Carbon and nitrogen isotopes · Trophic transfer · Estuaries Resale or republication not permitted without written consent of the publisher

\section{INTRODUCTION}

Oyster reefs have been identified as essential fish habitat for resident and transient species, and provide higher diversity and availability of food or a greater amount of higher quality food compared to other habitats (Breitburg 1999, Coen et al. 1999, Harding \& Mann 2001, Grabowski et al. 2005). Wells (1961) collected 303 different species that utilized oyster reefs, segregating species that use the reef primarily as shelter from those that depend on the reef for food. Fish species can be separated into 3 categories based on their dependence on oyster reefs for habitat: (1) resident oyster reef fishes are dependent on oyster reefs as their primary habitat, (2) facultative residents utilize the structured habitat of the reef and are not wide ranging species, and (3) transients that are wide ranging, especially as adults, use the reefs as feeding grounds (Breitburg 1999). The oyster reefresident organisms are consumed by finfish and crustacean species that may be recreationally or commercially valuable (Grabowski et al. 2005, Grabowski \& Peterson 2007).

Several species of fishes have been identified as oyster reef residents and include the naked goby Gobiosoma bosc, Florida blenny Chasmodes saburrae, striped blenny Chasmodes bosquianus, feather blenny Hypsoblennius hentz, skilletfish Gobiesox 
strumosus, gulf toadfish Opsanus beta, and oyster toadfish Opsanus tau (Zimmerman et al. 1989, Wenner et al. 1996, Breitburg 1999, Coen et al. 1999, Lenihan et al. 2001, Tolley \& Volety 2005, Tolley et al. 2006). These fishes use the oyster reef as spawning and feeding habitat and as shelter from predators. Resident oyster reef fishes typically feed on benthic invertebrates such as amphipods, mud crabs, and grass shrimps but can also prey on benthic fishes (Breitburg 1999, Lenihan et al. 2001). The naked goby, striped blenny, and skilletfish attach their eggs to the insides of recently dead, clean, articulated oyster shells and the oyster toadfish attaches its eggs to the underside of consolidated oyster shells (Breitburg 1999, Coen et al. 1999).

Fishes are not the only species that utilize oyster reefs as habitat. Several species of decapod crustaceans are found on oyster reefs: Petrolisthes armatus, Panopeus spp., Eurypanopeus depressus, Menippe mercenaria, Alpheus heterochaelis and Palaemonetes pugio (Zimmerman et al. 1989, Wenner et al. 1996, Coen et al. 1999, Luckenbach et al. 2005, Tolley \& Volety 2005, Tolley et al. 2005, 2006). The xanthid crab Panopeus herbstii is a predator of the eastern oyster and is generally found along the boundaries of oyster reefs (McDermott 1960, McDonald 1982). In contrast, the flatback mud crab E. depressus is an omnivore that uses the narrow spaces between dead shells and living oysters as shelter from predation and to avoid desiccation (Grant \& McDonald 1979, McDonald 1982). The porcelain crab Petrolisthes armatus is also abundant in oyster clusters and among dead articulated shells, perched atop oyster clusters and reaching up into the water column to filter feed (Caine 1975, Tolley \& Volety 2005). Penaeid and caridean shrimp such as grass shrimp Palaemonetes spp. are also frequently found on oyster reefs and serve as an important trophic link in both detrital and higher food webs (Coen et al. 1999). Grass shrimp also probably use the reef in order to avoid predators (Posey et al. 1999).

Trophic relationships in a specific environment can be inferred from previous dietary studies such as gut content analyses, but analysis of stable isotopes of several biologically important elements permit quantitative analysis of in situ trophic dynamics. Stable isotopes are especially useful in ecological studies focusing on food webs. Natural abundances of stable isotopes can be used as tracers and as a way of characterizing trophic structure. The measurement of naturally occurring stable isotopes in an organism allows for the examination of the dietary organization in a food web (DeNiro \& Epstein 1978, 1981,
Gearing 1991). Stable isotopes are used to determine both source and trophic level information, with sulfur and carbon isotopes typically used for source information (e.g. source of dietary carbon) and nitrogen isotopes used in trophic level information (i.e. trophic position) (DeNiro \& Epstein 1978, Fry \& Sherr 1984, Minagawa \& Wada 1984, Post 2002, Michener \& Kaufman 2007).

Many studies conducted in estuarine systems have shown the usefulness of stable isotope analysis in ecology. Haines \& Montague (1979) sampled stable carbon isotopes of major flora and fauna in a Georgia salt marsh and determined that $\delta^{13} \mathrm{C}$ values of invertebrates known to feed on Spartina closely matched the $\delta^{13} \mathrm{C}$ values of that plant, confirming it as a food source. Crabs and mussels in this same area were found to consume benthic diatoms and phytoplankton instead of Spartina (Haines \& Montague 1979). Another study examined food sources and trophic relationships for the blue crab Callinectes sapidus based on water quality differences in 2 estuaries in North Carolina (Bucci et al. 2007). Results showed that blue crab $\delta^{15} \mathrm{~N}$ values were elevated at sites with higher nitrate concentrations and that $\delta^{13} \mathrm{C}$ values increased with salinity (Bucci et al. 2007). The major food sources of the blue crab were determined to be vascular plant material and bivalves (Bucci et al. 2007).

Although previous studies have examined habitat utilization of oyster reefs, little work has been done examining trophic transfer using stable isotope compositions within oyster-reef communities, including decapod crustaceans and fishes. The objective of this study was to determine trophic transfer on oyster reefs with differing degrees of freshwater input in a subtropical environment using stable isotope compositions. Stable carbon and nitrogen isotope compositions were used to establish food sources of different species that make use of oyster reefs as habitat and that may consume the oysters themselves.

\section{MATERIALS AND METHODS}

\section{Study location}

Estero Bay was designated Florida's first aquatic preserve in 1966 and is located approximately $24 \mathrm{~km}$ south of Fort Myers and $26 \mathrm{~km}$ north of Naples, entirely within Lee County (Florida Department of Natural Resources 1983) (Fig. 1). Surface waters comprise over $38 \mathrm{~km}^{2}$ and the drainage basin $758.5 \mathrm{~km}^{2}$ (Florida Department of Natural Resources 


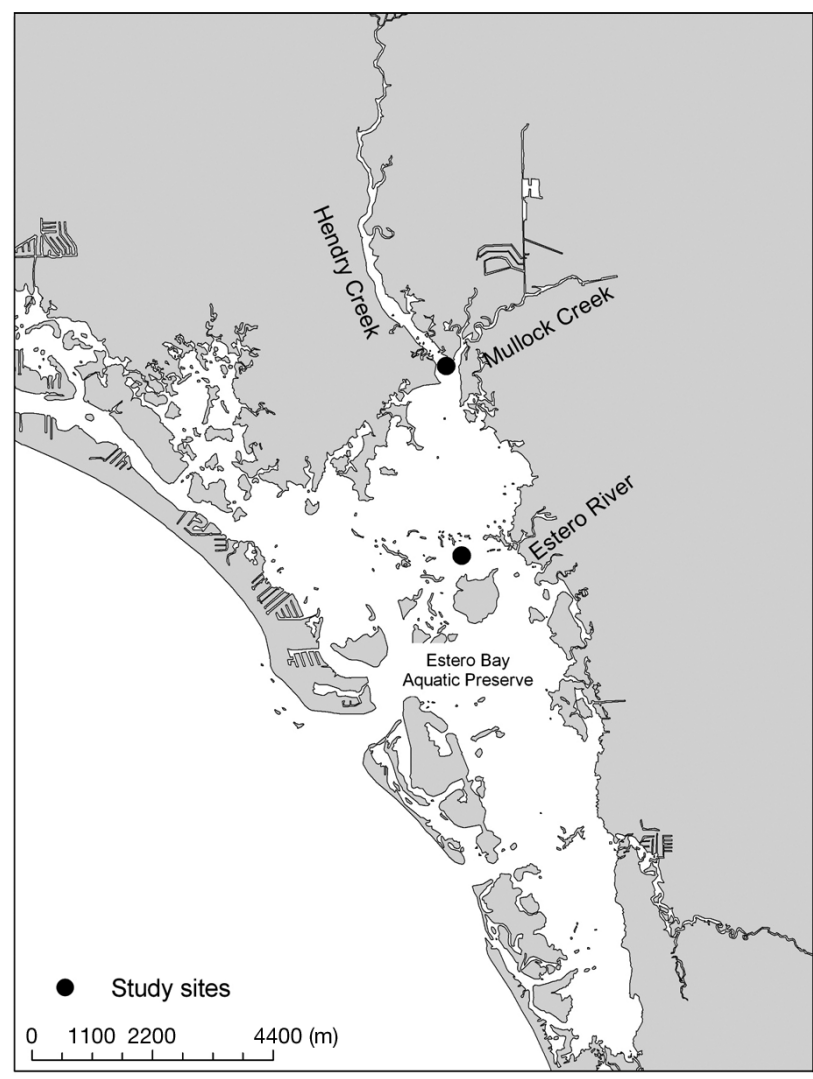

Fig. 1. Location of study sites in Estero Bay Aquatic Preserve in southwest Florida

1983). Estero Bay is supplied with freshwater by a number of small rivers and creeks, and major flushing is through tidal forces (Florida Department of Natural Resources 1983, Estero Bay Marine Laboratory 2004). This estuary is considered microtidal because its tidal amplitude is $\leq 2 \mathrm{~m}$, and the oyster reefs found here are mainly intertidal with limited vertical relief (Tolley et al. 2005, 2006). The lower part of the estuary is mostly protected, but its main tributaries, which include the Estero River and Hendry and Mullock Creeks, are experiencing increasing development in the upper portions of their watersheds (Tolley et al. 2005, 2006).

Two oyster reefs in Estero Bay were selected for this study, each experiencing different levels of freshwater inflow: one located near the mouth of the Estero River and the other located near the confluence of Hendry and Mullock Creeks (Fig. 1). Rainfall is seasonal in southwest Florida with rain generally falling from May to September. Estero River receives little freshwater runoff from the watershed and thus has higher salinities, while Hendry/Mullock Creek receives greater freshwater input from its watershed, including that from the City of Ft. Myers, via the Ten
Mile Canal, and thus has lower salinities, especially during summer months when heavy rainfall is common. The 2 sites were sampled quarterly starting in April 2008 and ending in February 2009 for a total of 4 sampling periods. Quarterly sampling was conducted to examine seasonal differences in trophodynamics.

\section{Sampling protocol}

Suspended particulate organic matter (POM), benthic microalgae, sediment, sinking POM, oysters (Crassostrea virginica), crabs (e.g. Eurypanopeus depressus, Petrolisthes armatus), shrimp (Palaemonetes spp. and Alpheus heterochaelis) and fishes (e.g. Opsanus beta, Chasmodes saburrae, Archosargus probatocephalus, Gobiosoma spp.) were sampled at each site during May, August and September (wet season), and in November 2008 and February 2009 (dry season). These species were chosen since they are the dominant species in oyster reefs from southwest Florida (Tolley \& Volety 2005). Triplicate samples (excluding oysters) were collected during each sampling effort.

\section{Organic matter sources collection and processing}

Organic matter sources including suspended $\mathrm{POM}$, sinking $\mathrm{POM}$, and benthic microalgae were at the base of the food chain in this community. Water samples for suspended POM were collected at each site in clean (acid-washed) polycarbonate bottles and then transported on ice back to the laboratory. There, water samples were vacuum-filtered on pre-combusted $\left(500^{\circ} \mathrm{C}, 4 \mathrm{~h}\right) 4.7 \mathrm{~cm}$ Whatman $\mathrm{GF} / \mathrm{F}$ glass microfiber filters, dried at 60 to $65^{\circ} \mathrm{C}$ in an oven for at least $24 \mathrm{~h}$, and stored in precombusted $\left(500^{\circ} \mathrm{C}, 4 \mathrm{~h}\right) 20 \mathrm{ml}$ glass scintillation vials at $-20^{\circ} \mathrm{C}$ until further processing (Riera \& Richard 1996, Loh et al. 2006, Decottignies et al. 2007).

Sediment traps for sinking POM as well as glass plates for benthic microalgae collection were deployed at each site for approximately $1 \mathrm{wk}$. Sediment traps were retrieved on the same sampling day as fish and decapods were collected from lift nets. The traps were transported on ice back to the laboratory where particles were filtered onto pre-combusted $\left(500^{\circ} \mathrm{C}, 4 \mathrm{~h}\right) 4.7 \mathrm{~cm}$ Whatman GF/F glass microfiber filters, dried at 60 to $65^{\circ} \mathrm{C}$ in an oven for at least $24 \mathrm{~h}$, and stored in pre-combusted $\left(500^{\circ} \mathrm{C}, 4 \mathrm{~h}\right) 20 \mathrm{ml}$ glass scintillation vials at $-20^{\circ} \mathrm{C}$ until further processing. 
Glass plates were transported on ice back to the laboratory where they were thoroughly washed under water. The benthic microalgae from the plates were scraped onto pre-combusted $\left(500^{\circ} \mathrm{C}, 4 \mathrm{~h}\right) 4.7 \mathrm{~cm}$ Whatman GF/F glass microfiber filters and dried at 60 to $65^{\circ} \mathrm{C}$ in an oven for at least $24 \mathrm{~h}$, then stored in pre-combusted $\left(500^{\circ} \mathrm{C}, 4 \mathrm{~h}\right) 20 \mathrm{ml}$ glass scintillation vials at $-20^{\circ} \mathrm{C}$ until further processing. Surface sediment samples were also collected using $20 \mathrm{ml}$ glass scintillation vials and stored at $-20^{\circ} \mathrm{C}$ until further processing.

\section{Oyster collection and processing}

Ten oysters were collected at each site and transported on ice back to the laboratory. Oysters were cleaned of epibionts and kept alive for $12 \mathrm{~h}$ in seawater prepared with deionized water and Instant Ocean® at the salinity of collection site to allow for evacuation of their gut contents (Gearing 1991, Decottignies et al. 2007, Dubois et al. 2007). Tissues from individual oysters were removed from the shells and stored in pre-combusted $\left(500^{\circ} \mathrm{C}, 4 \mathrm{~h}\right) 20 \mathrm{ml}$ glass scintillation vials at $-20^{\circ} \mathrm{C}$ until further processing (Dubois et al. 2007).

\section{Decapod and fish collection and processing}

Lift nets were deployed at each site just below mean low water in the intertidal zone on the living oyster reef for approximately $30 \mathrm{~d}$ per sampling effort (Tolley et al. 2005). Lift nets $\left(1 \mathrm{~m}^{2}\right)$ were constructed of $3.2 \mathrm{~cm}$ diameter PVC pipe frames and $6.4 \mathrm{~mm}$ delta-weave netting dipped in vinyl, with a net height of $0.5 \mathrm{~m}$ and a bottom made of $1.6 \mathrm{~mm}$ netting to prevent the escape of small organisms (Crabtree \& Dean 1982, Tolley et al. 2005). During deployment, a $1 \mathrm{~m}^{2}$ area of the bottom was cleared of oyster shell and the net secured to the substrate with two $45 \mathrm{~cm}$ lengths of PVC attached to PVC T-fittings placed through a zip-tie loop on the net (Tolley et al. 2005). Live oyster clusters of approximately 31 volume displacement were collected from the adjacent reef area and placed in each net (Tolley et al. 2005). Upon retrieval the oyster clusters were removed, placed in buckets, and sorted to collect any decapods or fishes from the clusters with the use of forceps. Any remaining decapods or fishes in the net and/or bucket were collected by hand or with the use of dip nets. All organisms were transported back to the laboratory and stored at $-20^{\circ} \mathrm{C}$ until processed. Organisms were subsequently identified to the lowest taxonomic level practical and then stored in separate pre-combusted $\left(500^{\circ} \mathrm{C}, 4 \mathrm{~h}\right) 20 \mathrm{ml}$ glass scintillation vials for each species at $-20^{\circ} \mathrm{C}$ until further processing.

\section{Stable isotope sample processing}

During processing, samples on filters were dried at 60 to $65^{\circ} \mathrm{C}$ in an oven for at least $24 \mathrm{~h}$, then underwent acid fumigation in a desiccator containing a small, pre-combusted $\left(500^{\circ} \mathrm{C}, 4 \mathrm{~h}\right)$ jar of $12 \mathrm{~N} \mathrm{HCl}$ (trace metal grade) for at least $24 \mathrm{~h}$. Filters were dried again at 60 to $65^{\circ} \mathrm{C}$ in an oven and then stored in precombusted $\left(500^{\circ} \mathrm{C}, 4 \mathrm{~h}\right) 20 \mathrm{ml}$ glass scintillation vials in a desiccator (Loh et al. 2006).

Individuals from each species, sediment, and microalgae were placed in separate, labeled precombusted $\left(500^{\circ} \mathrm{C}, 4 \mathrm{~h}\right) 20 \mathrm{ml}$ glass scintillation vials and freeze-dried for at least $48 \mathrm{~h}$. The samples were then ground to a fine powder using a clean (baked at $550^{\circ} \mathrm{C}$ ) porcelain mortar and pestle and placed back in their individual vials. Both mortar and pestle were rinsed with deionized water, wiped with a Kimwipe, and then rinsed with $10 \% \mathrm{HCl}$ and deionized water between samples. Once all samples for a site and month were ground, subsamples collected from each individual were weighed on pre-combusted $\left(500^{\circ} \mathrm{C}\right.$, $4 \mathrm{~h}$ ) aluminum dishes and dried at 60 to $65^{\circ} \mathrm{C}$ in an oven for at least $24 \mathrm{~h}$. Each sample was transferred to a pre-combusted $\left(500^{\circ} \mathrm{C}, 4 \mathrm{~h}\right) 7 \mathrm{ml}$ glass scintillation vial and acidified with drops of $10 \% \mathrm{HCl}$ (Trace Metal grade) to remove any carbonates (Boutton 1991, Gearing 1991, Loh et al. 2006). Vials were then placed in a fume hood on a hot plate set to $65^{\circ} \mathrm{C}$ to evaporate the acid for at least $12 \mathrm{~h}$. All samples were dried again at 60 to $65^{\circ} \mathrm{C}$ in an oven and then stored in a desiccator (Loh et al. 2006).

Micrograms ( 1 mg for animal samples, $\sim 30 \mathrm{mg}$ for sediment samples, and $\sim 3$ to $5 \mathrm{mg}$ for benthic microalgae samples) of the dried and acidified samples were weighed into clean (rinsed with acetone) $5 \times$ $9 \mathrm{~mm}$ (for ground samples) tin capsules and placed in a numbered 96-well plate. A small subsample of filters were weighed into clean (rinsed with acetone) $9 \times 10 \mathrm{~mm}$ (for samples on filters) tin capsules and placed in a numbered 96 well plate. The plates were sent to the University of California Davis Stable Isotope Facility for $\delta^{13} \mathrm{C}$ and $\delta^{15} \mathrm{~N}$ analyses (Loh et al. 2006). Tissue samples were analyzed for $\delta^{13} \mathrm{C}$ and $\delta^{15} \mathrm{~N}$ using a PDZ Europa ANCA-GSL elemental analyzer interfaced to a PDZ Europa 20-20 isotope ratio mass spectrometer (Sercon). Samples were com- 
busted at $1000^{\circ} \mathrm{C}$ in a reactor packed with chromium oxide and silvered cobaltous/cobaltic oxide. Following combustion, oxides were removed in a reduction reactor (reduced copper at $650^{\circ} \mathrm{C}$ ). $\mathrm{N}_{2}$ and $\mathrm{CO}_{2}$ were separated on a Carbosieve $\mathrm{GC}$ column $\left(65^{\circ} \mathrm{C}, 65 \mathrm{ml}\right.$ $\min ^{-1}$ ) before entering the isotope ratio mass spectrometer. Samples were analyzed using laboratory standards, which were selected to be compositionally similar to the samples being analyzed, and had been previously calibrated against National Institute of Standards and Technology Standard Reference Materials. Details of stable isotope analyses are available at: http://stableisotopefacility.ucdavis.edu/ 13cand15n. html

\section{Data analysis}

Isotope data were analyzed using principal component analysis after determining that the data was normally distributed using the Kolmogorov-Smirnov test (SPSS 16.0).

\section{RESULTS}

\section{Decapod and fish abundances}

At the Estero River site, 1823 individuals were collected, representing 21 species. At the Hendry/ Mullock Creeks site, 15 species were collected with a total of 462 individuals. Species in common for both sites were the snapping shrimp Alpheus heterochaelis; the crabs Panopeus simpsoni, Eurypanopeus depressus, Petrolisthes armatus, and Libinia spp.; and the fishes Opsanus beta, Gobiosoma robustum, Archosargus probatocephalus, Chasmodes saburrae, and Bathygobius soporator. Species found only at the Estero River site included the shrimps Palaemonetes pugio, Palaemonetes vulgaris, and Lysmata wurdemanni; the crabs Panopeus lacustris, Menippe mercenaria, and Rhithropanopeus harrisii; and the fishes Orthopristis chrysoptera, Lutjanus griseus, Lutjanus synagris, and Achirus lineatus. The most abundant species collected at this site was the green porcelain crab Petrolisthes armatus with 973 individuals. Species found only at the Hendry/Mullock Creeks site included the fishes Gobiosoma bosc, Lophogobius cyprinoides, Gobiesox strumosus, and Lupinoblennius nicholsi. The most abundant species collected at this site was the flatback mud crab Eurypanopeus depressus with 263 individuals (Table 1).

\section{Isotope analysis}

Estero River

Fishes and shrimp were more enriched in $\delta^{15} \mathrm{~N}$, ranging from 2.5 to $4.4 \%$ compared to crabs and oysters for all sampling periods at the Estero River site. Enrichment in $\delta^{13} \mathrm{C}$ was not as clear in fishes, shrimp, crabs, and oysters. Organic matter sources were depleted in $\delta^{15} \mathrm{~N}$ compared to all other samples and with the exception of surface sediments, were depleted in $\delta^{13} \mathrm{C}$ when compared to crabs, shrimp, and fishes (Table 2). Surface sediments at this site were all enriched in $\delta^{13} \mathrm{C}(-12.42$ to $-6.16 \%$; see 'Discussion').

In May 2008, the 4 identified fish $\left(\delta^{15} \mathrm{~N}\right.$ of 7.39 to $8.11 \%$ ) and 3 identified shrimp $\left(\delta^{15} \mathrm{~N}\right.$ of 6.42 to $8.19 \%$ ) species were more enriched in $\delta^{15} \mathrm{~N}$ compared to crabs (3.27 to $5.62 \%$ o) and oysters (4.26\%o) (Fig. 2a, Table 2). In September 2008, the organic matter sources were depleted in $\delta^{13} \mathrm{C}(-25.61$ and $-21.64 \%$ ) compared to all other samples, which ranged from -22.38 to $-17.34 \%$ (Fig. 2b, Table 2). The 2 identified fish species were more enriched in $\delta^{15} \mathrm{~N}(6.90$ to $7.30 \%$ ) compared to crabs (3.58 to $5.88 \%$ ), oysters $(4.73 \%$ ), and shrimp (5.19 to $6.42 \%$ ) (Fig. 2b, Table 2). In November 2008, the 3 identified fish species were more enriched in $\delta^{15} \mathrm{~N}$ (7.31 to $9.45 \%$ ) compared to oysters (4.55 to $5.65 \%$ o), crabs (4.01 to $5.70 \%$ ), and shrimp (6.26\%o) (Fig. 2c, Table 2). Sinking POM had similar $\delta^{15} \mathrm{~N}$ and $\delta^{13} \mathrm{C}$ compositions to crabs and shrimp (4.91 and $-17.18 \%$, respectively) (Fig. 2c, Table 2). In February 2009, the 4 identified fish $\left(\delta^{15} \mathrm{~N}\right.$ of 8.02 to $9.67 \%$ ) and 3 identified shrimp ( $\delta^{15} \mathrm{~N}$ of 6.87 to $8.85 \%$ ) species were more enriched in $\delta^{15} \mathrm{~N}$ compared to oysters (5.32\%) and crabs (4.24 to $5.91 \%$ ) (Fig. 2d, Table 2). Organic matter sources had a wide range of $\delta^{13} \mathrm{C}$ values, from -22.59 to $-12.75 \%$, with sinking POM having $\delta^{13} \mathrm{C}$ compositions similar to sediment $(-12.75$ and $-12.42 \%$, respectively) (Fig. $2 \mathrm{~d}$, Table 2 ).

In September and November, shrimp occupied the same trophic level as crabs and oysters. In November, sinking POM was at the same trophic level as the oysters, crabs and shrimp. Although sinking POM was at this second trophic level, the other 2 organic matter sources (suspended POM and benthic microalgae) were at the lowest trophic level. In February, with the exception of benthic microalgae which had an average $\delta^{15} \mathrm{~N}$ value that was similar to the 2 crabs Petrolisthes armatus and Eurypanopeus depressus, the organic matter sources were at the lowest trophic level. 
O O H

000000 h

$0,4000 \mathrm{n}$ H.

$0000 m 00 m_{n}^{n} 0000 n-m 0000-100 n-0$ ก

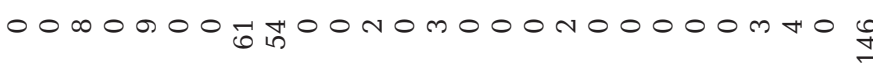

애

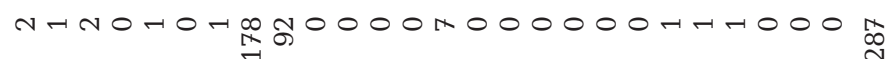

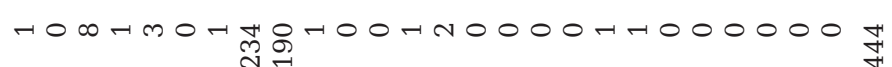

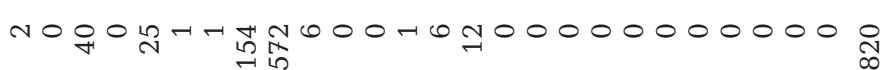

$\ln 0$ n

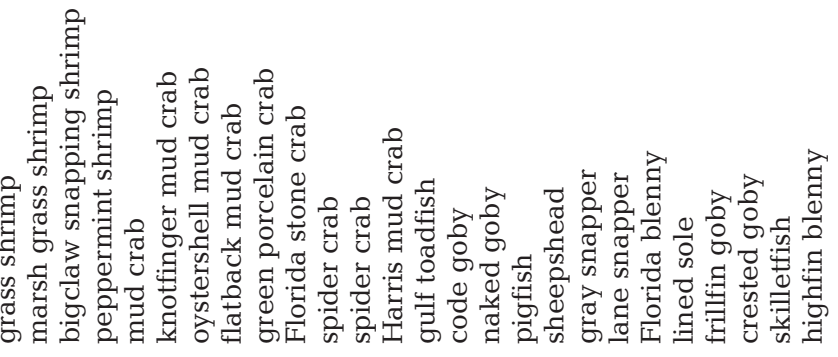

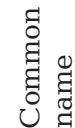

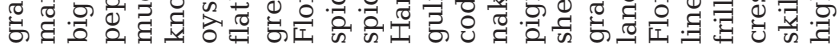

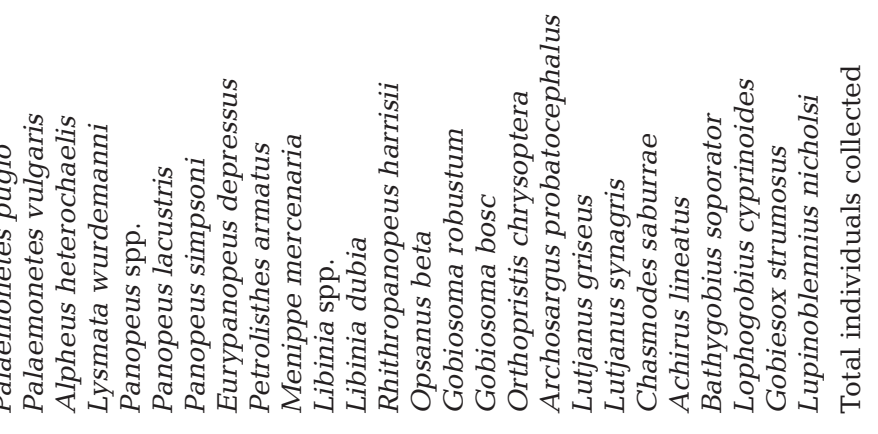

Animals are enriched by about $1 \%$ in the heavier isotope $\left({ }^{13} \mathrm{C}\right)$ compared to their diet. Thus, trophic level identification is based on $\delta^{13} \mathrm{C}$ and $\delta^{15} \mathrm{~N}$ values (1\%o and $3 \%$ per trophic level, respectively). Based on the $\delta^{13} \mathrm{C}$ values, the carbon sources for fishes were determined to be from other fishes, shrimp, crabs, worms, oysters, benthic microalgae, and suspended POM (Fig. 2). Carbon sources for shrimp species were from other shrimp, worms, amphipods, crabs, sinking POM, suspended POM, and benthic microalgae (Fig. 2). Carbon sources for crab species were from other crabs, shrimp, oysters, worms, amphipods, benthic microalgae, sinking POM, and suspended POM (Fig. 2). The carbon sources for oysters were from benthic microalgae, sinking POM, and suspended POM (Fig. 2).

\section{Hendry/Mullock Creeks}

At the Hendry/Mullock Creeks site, fishes and shrimp were more enriched in $\delta^{15} \mathrm{~N}$, with an average range of 1.1 to $3.9 \%$, relative to crabs and oysters for all sampling periods. Organic matter sources, crabs, shrimp and fishes all had similar $\delta^{13} \mathrm{C}$ values, with an average range of -25.3 to $-24.9 \%$, but oysters were less enriched at $-27.5 \%$. Organic matter sources were depleted in $\delta^{15} \mathrm{~N}$ compared to all other samples and, with the exception of surface sediments, were depleted in $\delta^{13} \mathrm{C}$ when compared to crabs, shrimp, and fish (Table 3). Surface sediments at this site were all enriched in $\delta^{13} \mathrm{C}$ (-16.65 to $-9.66 \%$; see 'Discussion').

In May 2008, the 4 identified fish species were more enriched in $\delta^{15} \mathrm{~N}$ (7.95 to $9.15 \%$ ) compared to crabs (3.34 to $4.00 \%$ ), shrimp (5.65\%) and oysters (4.81\%) (Fig. 3a, Table 3). Organic matter sources all had similar $\delta^{15} \mathrm{~N}$ values, ranging from 2.81 to $3.14 \%$, but their $\delta^{13} \mathrm{C}$ values varied widely, ranging from -26.61 to 


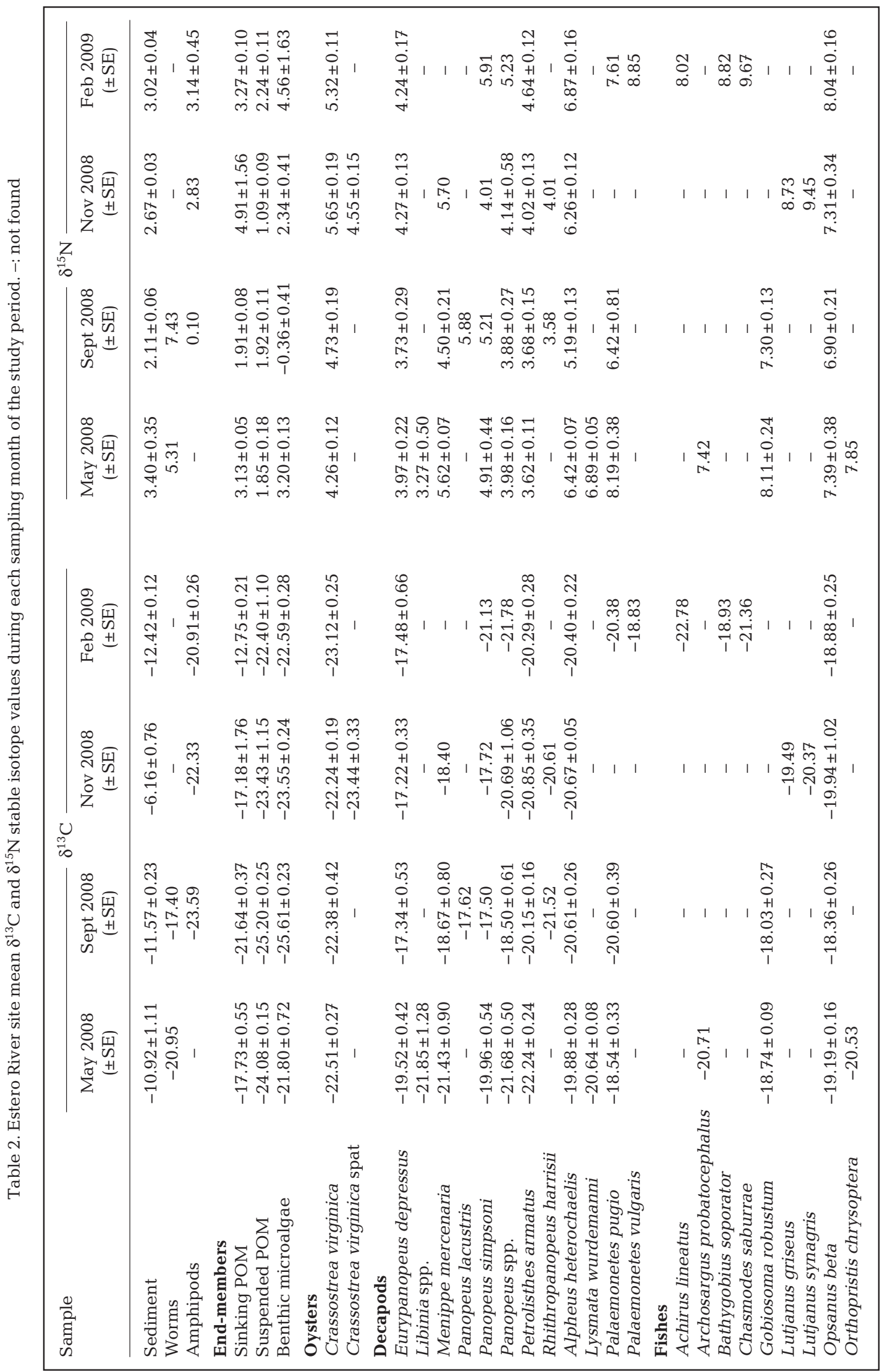




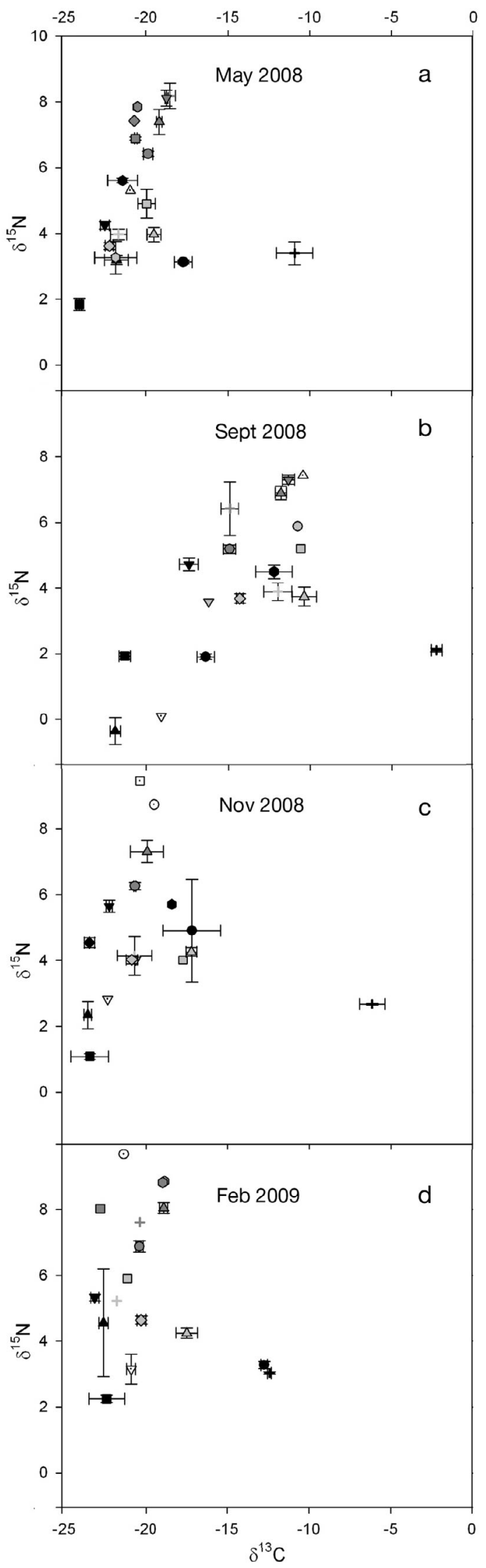

+ Sediment

- Sinking POM

- Suspended POM

- Benthic microalgae

- Crassostrea virginica

- Menippe mercenaria

Panopeus spp.

$\square$ Panopeus simpsoni

$\triangle$ Eurypanopeus depressus

$\diamond$ Petrolisthes armatus

- Libinia spp.

+ Palaemonetes pugio

- Alpheus heterochaelis

- Lysmata wurdemanni

$\triangle$ Opsanus beta

$\nabla$ Gobiosoma robustum

$\diamond$ Archosargus probatocephalus

- Orthopristis chrysoptera

$\triangle$ Worm species

+ Sediment

- Sinking POM

- Suspended POM

- Benthic microalgae

- Crassostrea virginica

- Menippe mercenaria

Panopeus spp.

- Panopeus lacustris

$\square$ Panopeus simpsoni

$\triangle$ Eurypanopeus depressus

$\nabla$ Rhithropanopeus harrisii

$\checkmark$ Petrolisthes armatus

+ Palaemonetes pugio

- Alpheus heterochaelis

$\triangle$ Opsanus beta

$\nabla$ Gobiosoma robustum

$\triangle$ Worm species

$\nabla$ Amphipod species

+ Sediment

- Sinking POM

- Suspended POM

- Benthic microalgae

- Crassostrea virginica

- Crassostrea virginica spat

- Menippe mercenaria

Panopeus spp.

- Panopeus simpsoni

$\triangle$ Eurypanopeus depressus

$\nabla$ Rhithropanopeus harrisii

$\checkmark$ Petrolisthes armatus

- Alpheus heterochaelis

$\triangle$ Opsanus beta

- Lutjanus griseus

$\square$ Lutjanus synagris

$\nabla$ Amphipod species

+ Sediment

- Sinking POM

- Suspended POM

- Benthic microalgae

- Crassostrea virginica

+ Panopeus spp.

- Panopeus simpsoni

$\triangle$ Eurypanopeus depressus

$\diamond$ Petrolisthes armatus

- Palaemonetes vulgaris

+ Palaemonetes pugio

- Alpheus heterochaelis

口 Achirus lineatus

$\triangle$ Opsanus beta

- Bathygobius soporator

- Chasmodes saburrae

$\nabla$ Amphipod species
$-22.21 \%$ (Fig. 3a, Table 3). In September 2008, the 6 identified fish species were more enriched in $\delta^{15} \mathrm{~N}$ (7.64 to $8.74 \%$ ) compared to oysters $(5.59 \%$ o), shrimp (5.55\%o), and crabs (4.02 to $6.09 \%$ ) (Fig. 3b, Table 3). Organic matter sources ranged from -28.69 to $-20.84 \%$ for $\delta^{13} \mathrm{C}$ and from 1.09 to $2.73 \%$ for $\delta^{15} \mathrm{~N}$ (Fig. 3b, Table 3). In November 2008, the 6 identified fish species were more enriched in $\delta^{15} \mathrm{~N}$ (8.10 to $9.41 \%$ ) compared to oysters (4.79 to $5.54 \%$ ), crabs (4.46 to $6.45 \%$ ) and shrimp (6.62\%o) (Fig. 3c, Table 3). Organic matter sources showed a wide variation in $\delta^{15} \mathrm{~N}$ values ranging from 0.69 to $3.10 \%$ and a similar variation in $\delta^{13} \mathrm{C}$ values ranging from -27.14 to $-24.95 \%$ o (Fig. 3c, Table 3). In February 2009, the majority of the fish species had similar values for $\delta^{15} \mathrm{~N}$ and $\delta^{13} \mathrm{C}$ ranging from 9.20 to $10.24 \%$ ond -25.56 to $-23.88 \%$, respectively, but Opsanus beta differed with a $\delta^{15} \mathrm{~N}$ value of $7.34 \%$ and a $\delta^{13} \mathrm{C}$ value of $-19.56 \%$ (Fig. $3 \mathrm{~d}$, Table 3). Crabs, oysters, and shrimp had a wide variation in $\delta^{15} \mathrm{~N}$ and $\delta^{13} \mathrm{C}$ values ranging from 5.00 to $7.32 \%$ and -27.29 to $-22.27 \%$, respectively (Fig. 3d, Table 3 ). Organic matter sources also exhibited wide variation, with $\delta^{15} \mathrm{~N}$ values ranging from 2.31 to $5.71 \%$ and $\delta^{13} \mathrm{C}$ values ranging from -26.20 to $-25.00 \%$ (Fig. 3d, Table 3).

\section{Principal component analysis}

Principal component analysis (PCA) was used to identify trends in stable isotope data. Only 9 sample types were found at both sites during all sampling periods, so only these were used in the analysis: sediment (Sed), sinking particulate organic matter (SinkPOM), suspended particulate organic matter (SuspPOM), benthic microalgae (BMA), oysters (Oyster), Eurypanopeus depres-

Fig. 2. Mean stable isotope values with $\delta^{13} \mathrm{C}$ versus $\delta^{15} \mathrm{~N}$ for Estero River site. Error bars represent \pm standard error. (a) May 2008, (b) September 2008, (c) November 2008, (d) February 20009 


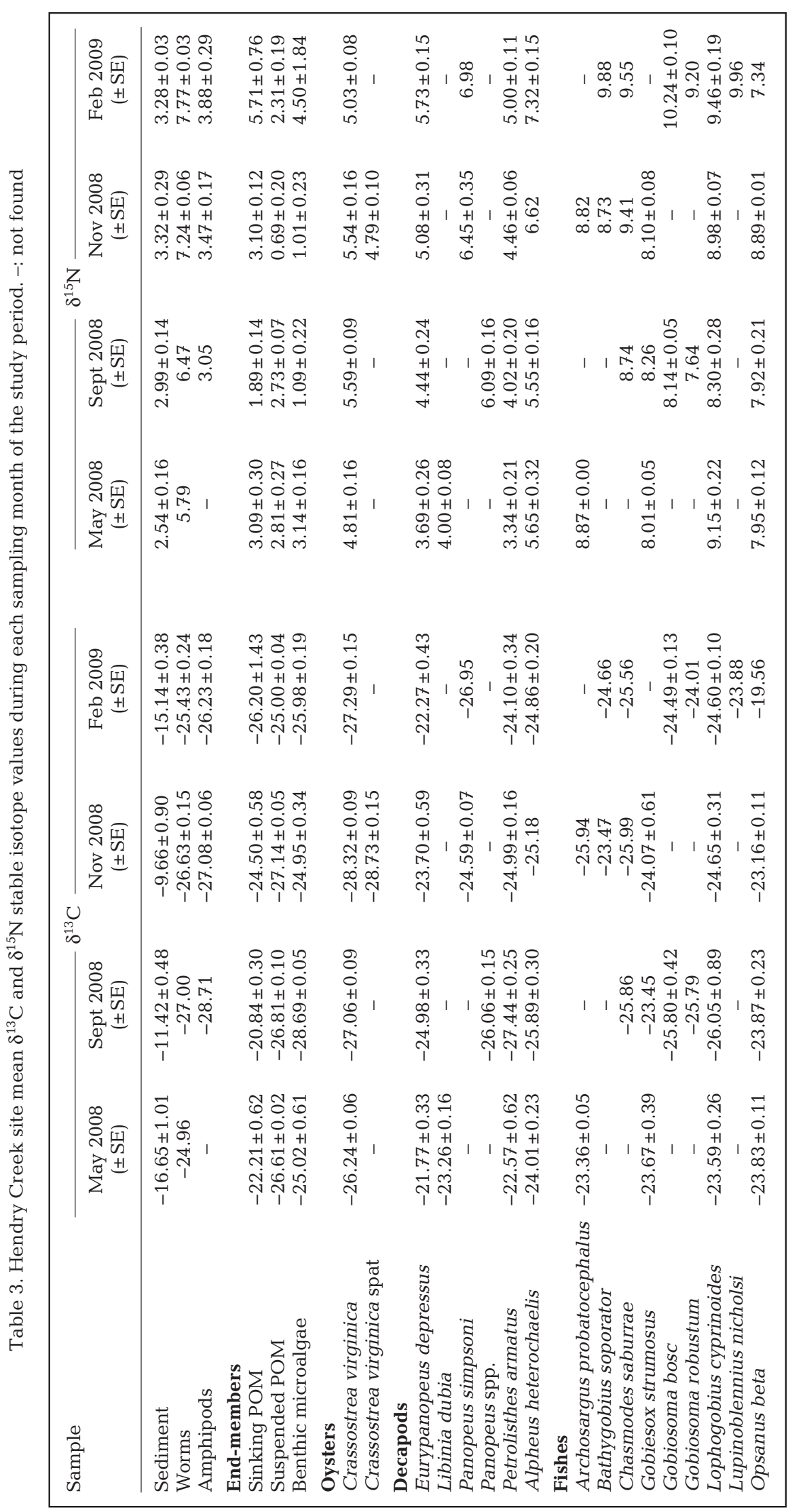

sus (Eurypanopeus), Petrolisthes armatus (Petrolisthes), Alpheus heterochaelis (Alpheus), and Opsanus beta (Opsanus). As sediment samples had isotope values that differed greatly from all other samples, PCA was run a second time excluding sediment samples to determine how much the inclusion of sediment samples influenced the analysis.

Using PCA, the $\delta^{13} \mathrm{C}$ values for all samples including sediment were described by 2 factors that together explained $82.4 \%$ of the variance (Factor 1: 71.3\%; Factor 2: 11.1\%). Loadings for Factor 1 were most positive for Alpheus, Eurypanopeus, and Oyster, with Sed being the least positive (Fig. 4a). All Estero River samples had positive scores for Factor 1, whereas all Hendry/Mullock Creeks samples had negative scores (Fig. 4b). Loadings for Factor 2 were most positive for Sed and most negative for Petrolisthes and Opsanus (Fig. 4a). Estero River November 2008 and Hendry/Mullock Creeks September 2008 and November 2008 samples had the most positive scores for Factor 2, whereas Hendry/Mullock Creeks February 2009 and May 2008 samples had the most negative scores along Factor 2 (Fig. 4b). Loadings indicated that all samples had similar $\delta^{13} \mathrm{C}$ values except for sediment. Scores indicated that $\delta^{13} \mathrm{C}$ values for Hendry/Mullock Creeks were distinct from $\delta^{13} \mathrm{C}$ values of Estero River.

The $\delta^{13} \mathrm{C}$ values for all samples excluding sediment were described by 2 factors that together explained $87.2 \%$ of the variance (Factor 1: $78.7 \%$; Factor 2: 8.5\%). Loadings for Factor 1 were most positive for Alpheus, Eurypanopeus, and Oyster and least positive for SinkPOM (Fig. 5a). All Estero River samples had positive scores for Factor 1, whereas all Hendry/Mullock Creeks samples had negative scores for Factor 1 (Fig. 5b). Loadings for Factor 2 were most positive for 


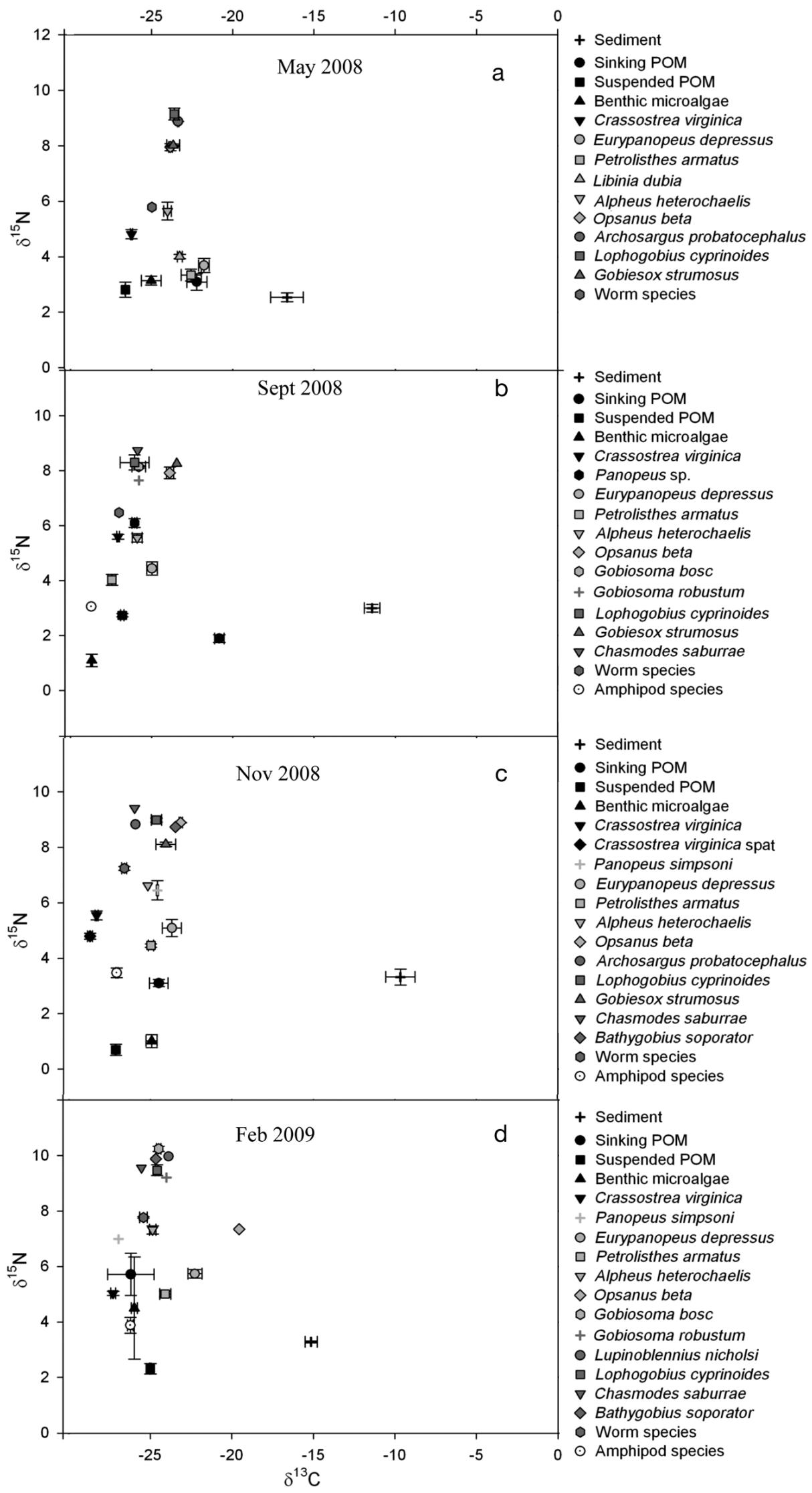

SinkPOM and most negative for Opsanus (Fig. 5a). Samples collected from Hendry/Mullock Creeks in February 2009 and from Estero River in September 2008 had the most negative scores for Factor 2, while Hendry/Mullock Creeks September 2008 and Estero River February 2009 samples had the most positive scores (Fig. 5b). Loadings indicated that $\delta^{13} \mathrm{C}$ values for SuspPOM, Oyster, Alpheus, Eurypanopeus, and Petrolisthes were more similar to one another based on their ordination compared to the other samples. Scores indicated that $\delta^{13} \mathrm{C}$ values for Hendry/Mullock Creeks were distinct from $\delta^{13} \mathrm{C}$ values for Estero River. Loadings and scores for all samples excluding sediment were different from the loadings and scores for all samples including sediment.

The $\delta^{15} \mathrm{~N}$ values for all samples including sediment were described by 2 factors that together explained $68.2 \%$ of the variance (Factor 1: $47.8 \%$; Factor 2: $20.4 \%$ ). Loadings for Factor 1 were most positive for Alpheus and most negative for SuspPOM (Fig. 6a). The Hendry/ Mullock Creeks February 2009 sample had the most positive score for Factor 1, whereas the Estero River September 2008 sample had the most negative score (Fig. 6b). Loadings for Factor 2 were most positive for SuspPOM and BMA and most negative for Opsanus and Oyster (Fig. 6a). The Estero River May 2008 and Hendry/Mullock Creeks February 2009 samples had the most positive scores for Factor 2, whereas the Hendry/Mullock Creeks November 2008 sample had the most negative score

Fig. 3. Mean stable isotope values with $\delta^{13} \mathrm{C}$ versus $\delta^{15} \mathrm{~N}$ for Hendry/Mullock Creeks site. Error bars represent \pm standard error. (a) May 2008, (b) September 2008, (c) November 2008, (d) February 2009 

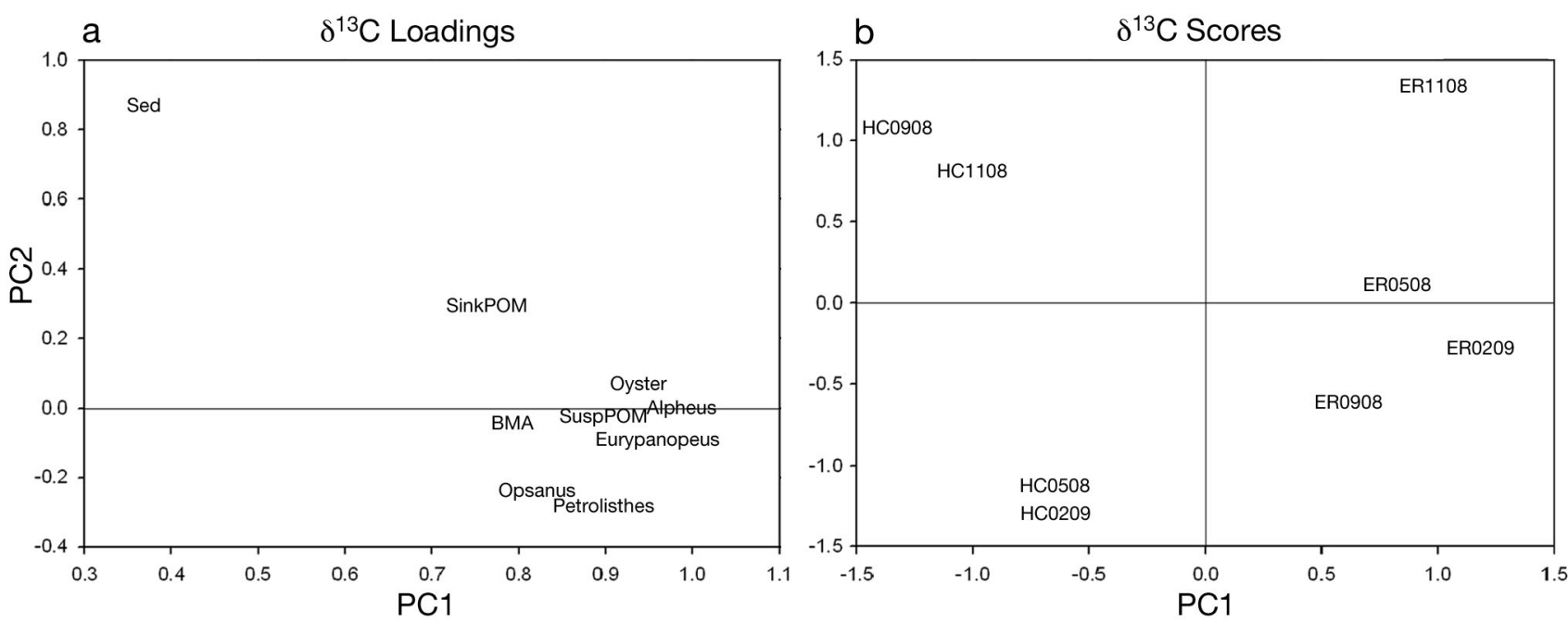

Fig. 4. Principal component analysis of $\delta^{13} \mathrm{C}$ samples including sediment. (a) $\delta^{13} \mathrm{C}$ loadings, (b) $\delta^{13} \mathrm{C}$ scores. ER: Estero River; HC: Hendry/Mullock Creeks; sample dates given as mmyy
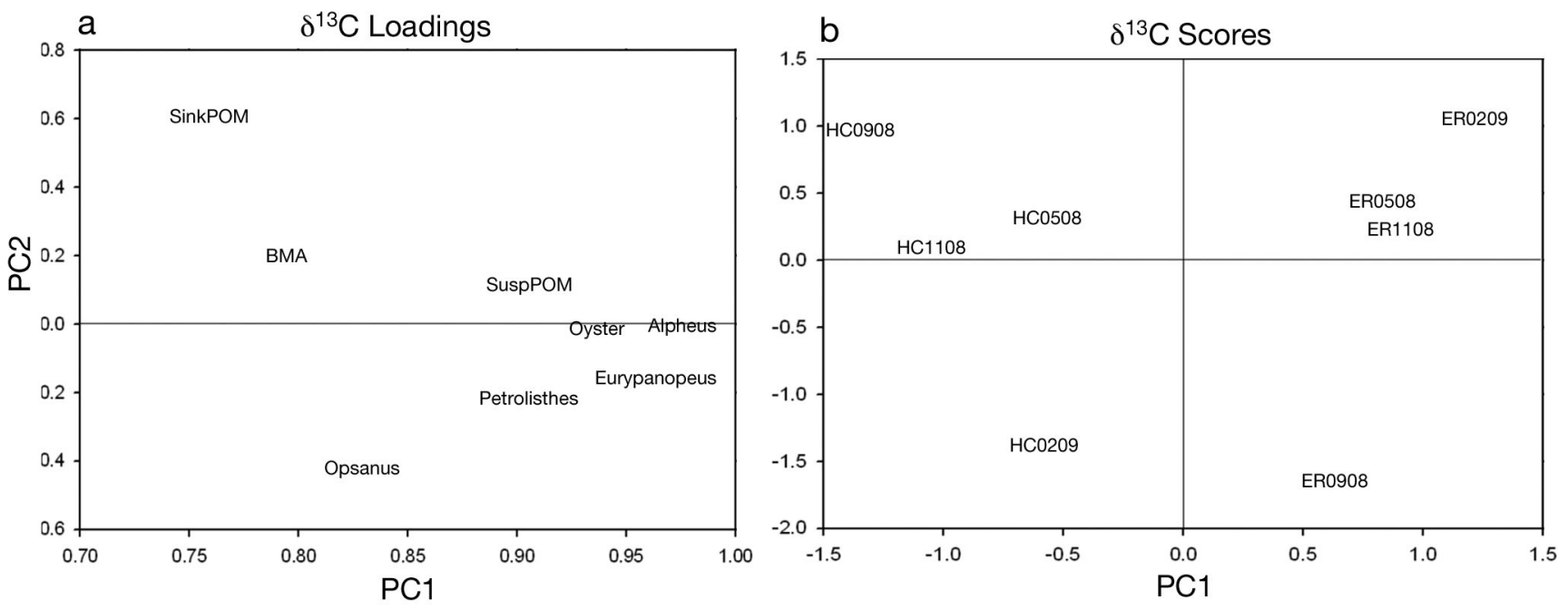

Fig. 5. Principal component analysis of $\delta^{13} \mathrm{C}$ samples excluding sediment. (a) $\delta^{13} \mathrm{C}$ loadings, (b) $\delta^{13} \mathrm{C}$ scores. ER: Estero River; HC: Hendry/Mullock Creeks; sample dates given as mmyy

(Fig. 6b). Loadings indicated that $\delta^{15} \mathrm{~N}$ values for Opsanus and Oyster were similar to one another and that Petrolisthes and Eurypanopeus had similar $\delta^{15} \mathrm{~N}$ values. Scores indicated that $\delta^{15} \mathrm{~N}$ values for both sites were similar to each other based on sampling date: May samples had similar $\delta^{15} \mathrm{~N}$ values, February samples were similar to one another, etc.

The $\delta^{15} \mathrm{~N}$ values for all samples excluding sediment were described by 2 factors that together explained $70.3 \%$ of the variance (Factor 1: $47.3 \%$; Factor 2: $23.0 \%$ ). Loadings for Factor 1 were most positive for Alpheus and most negative for SuspPOM (Fig. 7a). The Hendry/Mullock Creeks February 2009 sample had the most positive score for Factor 1, whereas the
Estero River September 2008 sample had the most negative score (Fig. 7b). Loadings for Factor 2 were most positive for SuspPOM and BMA and most negative for Opsanus and Oyster (Fig. 7a). The Estero River May 2008 and Hendry/Mullock Creeks February 2009 samples had the most positive scores for Factor 2, whereas the Hendry/Mullock Creeks November 2008 sample had the most negative score (Fig. 7b). Loadings and scores for all samples excluding sediment were similar to loadings and scores for all samples including sediment.

Overall, the inclusion of sediment samples in the analyses influenced the loadings and scores for $\delta^{13} \mathrm{C}$ but not for $\delta^{15} \mathrm{~N}$. Similarities in $\delta^{13} \mathrm{C}$ values were sepa- 

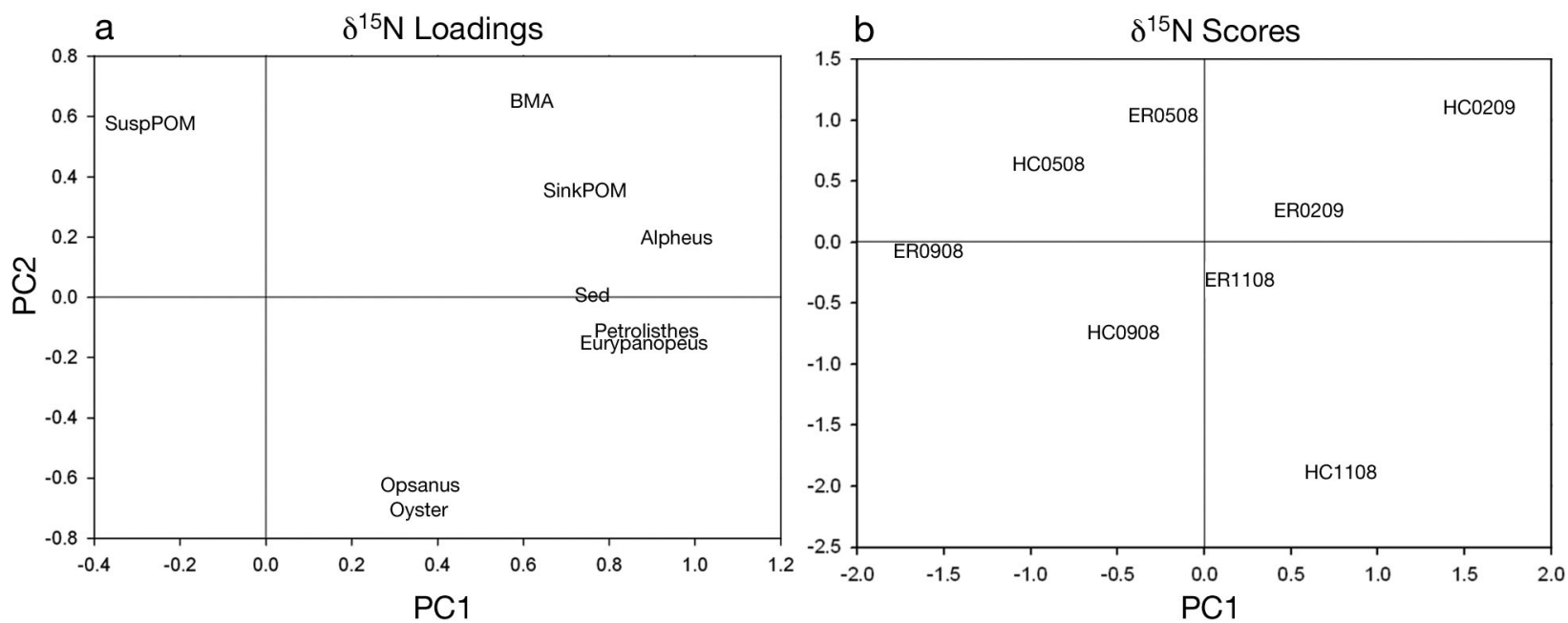

Fig. 6. Principal component analysis of $\delta^{15} \mathrm{~N}$ samples including sediment. (a) $\delta^{15} \mathrm{~N}$ loadings, (b) $\delta^{15} \mathrm{~N}$ scores. ER: Estero River; HC: Hendry/Mullock Creeks; sample dates given as mmyy
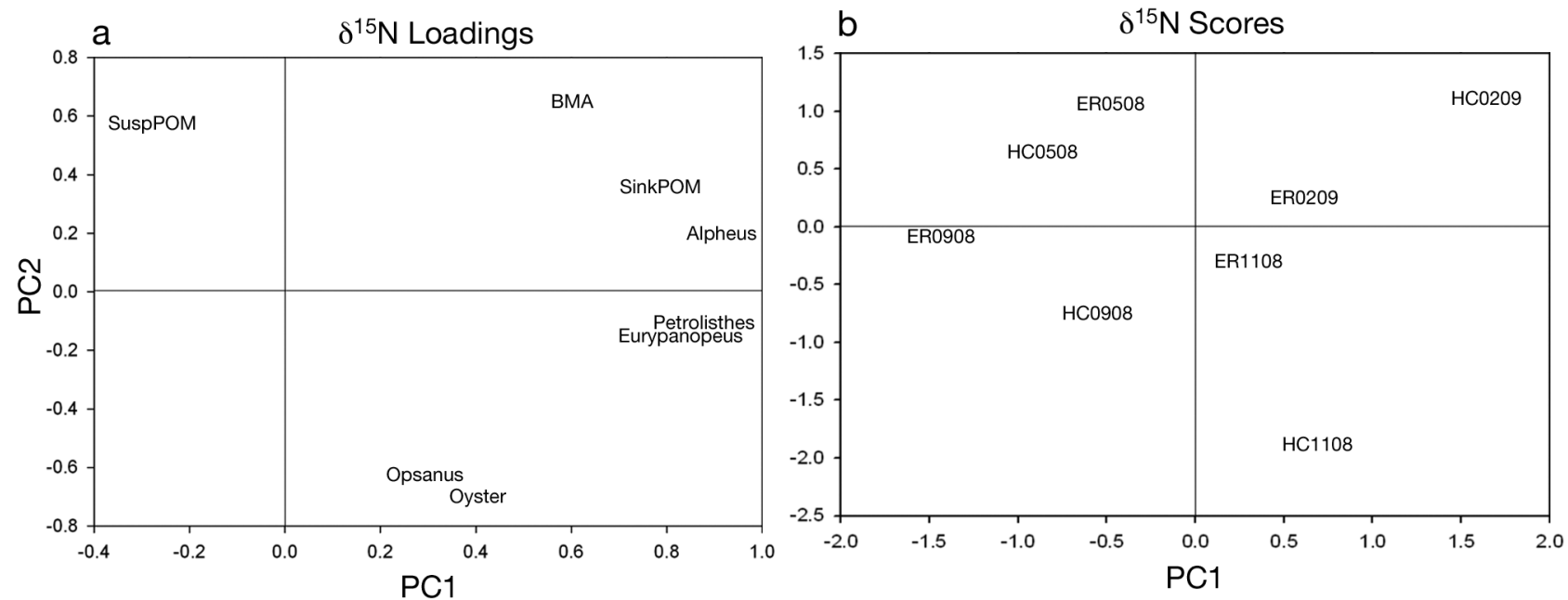

Fig. 7. Principal component analysis of $\delta^{15} \mathrm{~N}$ samples excluding sediment. (a) $\delta^{15} \mathrm{~N}$ loadings, (b) $\delta^{15} \mathrm{~N}$ scores. ER: Estero River;

HC: Hendry/Mullock Creeks; sample dates given as mmyy

rated based on site, but all samples had similar values overall. Similarities in $\delta^{15} \mathrm{~N}$ values were separated based on sampling period. Although primary consumers had similar $\delta^{15} \mathrm{~N}$ values, the secondary consumer (Opsanus) had a $\delta^{15} \mathrm{~N}$ value similar to oysters.

\section{DISCUSSION}

The objective of this study was to determine oyster reef trophic dynamics by investigating isotopic composition of reef-resident decapod crustaceans and fishes and their possible food sources, including oysters. Many investigators have used $\delta^{13} \mathrm{C}$ and $\delta^{15} \mathrm{~N}$ isotope values to determine both the source of carbon for an organism and its trophic level (DeNiro \& Epstein 1978, 1981, Minagawa \& Wada 1984, Peter- son \& Fry 1987). Distinct trophic levels can be identified based on average $\delta^{15} \mathrm{~N}$ values because animals are enriched by $3 \%$ in the heavier isotope $\left({ }^{15} \mathrm{~N}\right) \mathrm{com}-$ pared to their diet. Overall, fishes and shrimp are at the highest trophic level and are considered secondary consumers, with crabs and oysters as primary consumers, and organic matter sources at the lowest trophic level. Based on $\delta^{13} \mathrm{C}$ and $\delta^{15} \mathrm{~N}$ values obtained in this study, reef-resident organisms consume other organisms found on the reef and/or primary producers and detrital organic matter on the reef.

The isotopic composition of an organism is a reflection of the isotopic composition of its diet (DeNiro \& Epstein 1978, 1981, Gearing 1991). In general, $\delta^{13} \mathrm{C}$ and $\delta^{15} \mathrm{~N}$ are more positive (enriched) in organisms higher in the trophic level relative to their diet because consumers retain the stable isotope signa- 
tures of the foods they assimilate (i.e. you are what you eat) (DeNiro \& Epstein 1978, 1981). The carbon isotopic composition of animals reflects their diet within about $1 \%$, indicating a small enrichment in the heavier isotope $\left({ }^{13} \mathrm{C}\right)$ in the animal relative to its diet (DeNiro \& Epstein 1978, Michener \& Kaufman 2007). There are several biological processes that can account for this enrichment in carbon: (1) loss of ${ }^{12} \mathrm{C}$ during respiration, (2) uptake of ${ }^{13} \mathrm{C}$ during digestion, or (3) metabolic fractionation during synthesis of different tissue types (Michener \& Kaufman 2007). The nitrogen isotopic composition reflects enrichment by 3 to $4 \%$ in the heavier isotope $\left({ }^{15} \mathrm{~N}\right)$ in the animal relative to its diet (DeNiro \& Epstein 1981, Minagawa \& Wada 1984, Michener \& Kaufman 2007). Enrichment occurs due to excretion of ${ }^{15} \mathrm{~N}$-depleted nitrogen, usually in the form of urea and ammonia (Michener \& Kaufman 2007).

\section{Trophic dynamics - decapods}

Eurypanopeus depressus and Petrolisthes armatus were the most abundant species found on oyster reefs in Estero Bay, both in this study and in previous work by Tolley et al. $(2005,2006)$. In the current study, E. depressus was more abundant at the Hendry/Mullock Creeks site and $P$. armatus was more abundant at the Estero River site (Table 1). $P$. armatus is a stenohaline crab and has a lower tolerance to reduced salinity compared to E. depressus, a euryhaline species (Shumway 1983). As salinity was generally higher at the Estero River site (Fig. 8), the greater abundance of $P$. armatus there was not unexpected. E. depressus is an omnivore and consumes primarily algae and detritus, with gut contents in-

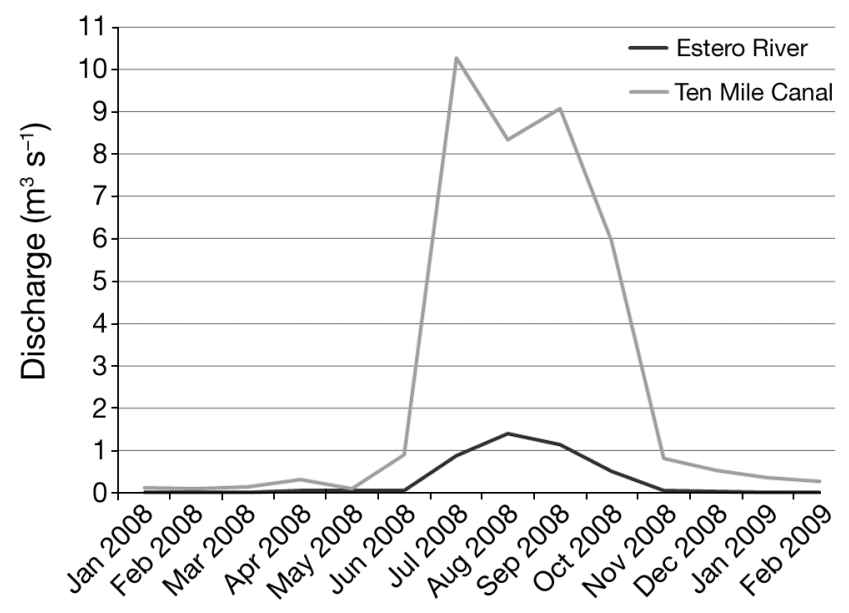

Fig. 8. Discharge data for Estero River and Ten Mile Canal cluding shell fragments, polychaete setae, and pieces of crustacean exoskeleton (McDonald 1982). This species has also been known to feed on oyster spat and bivalves (McDermott 1960, Milke \& Kennedy 2001). Stable carbon isotope values indicated that the food source for $E$. depressus is other crabs, sinking POM, benthic microalgae, worms, and shrimp; these results are consistent with known food sources identified by other investigators. In contrast, $P$. armatus primarily sweeps seston from the water column and its stable carbon isotope values indicated that its food source is sinking POM, benthic microalgae, and suspended POM. This species is able to feed directly on benthic microalgae by scraping shells with its chelae and moving the material to its mouth (Caine 1975).

Alpheus heterochaelis is another abundant organism found on oyster reefs in this study. This shrimp uses its big-claw to stun or even kill small prey such as grass shrimp and gobies (Hazlett 1962, Herberholz \& Schmitz 1998). Stomach contents have included vascular plant detritus, inorganic particles, copepods, and amphipods, indicating an omnivorous feeding regime (Williams 1984). Nolan \& Salmon (1970) reported that, in the laboratory, this species will graze on algae attached to shells. Food sources for $A$. heterochaelis identified in the current study include benthic microalgae, worms, sinking POM, grass shrimp, suspended POM, and amphipods, and are thus consistent with previous studies.

The $\delta^{13} \mathrm{C}$ values determined in this study indicated that the crabs Panopeus spp., Panopeus simpsoni, and Menippe mercenaria feed directly on oysters. These species are known to consume oysters and other bivalves (Menzel \& Hopkins 1956, McDermott 1960, Reames \& Williams 1983, Hughes \& Grabowski 2006). Stable carbon isotope values for both $P$. simpsoni and $P$. lacustris indicated that their food sources are other crabs, oysters, shrimp, worms, amphipods, and benthic microalgae. P. simpsoni has been known to feed on algae, bryozoans, and smaller crabs (Reames \& Williams 1983). Stable carbon isotope values for $M$. mercenaria indicated that its food sources are oysters, other crabs, shrimp, and worms.

\section{Trophic dynamics - oysters}

In this study, Crassostrea virginica was found to consume benthic microalgae and both sinking and suspended POM (Tables 2 \& 3, Figs. 2 \& 3). Oysters can feed directly on benthic microalgae when it is resuspended in the water column (Fukumori et al. 2008). Other studies have shown similar food sources 
being consumed. Conkright \& Sackett (1986) found that oysters in Tampa Bay, Florida, utilized both phytoplankton and terrestrial carbon. Peterson \& Howarth (1987) found that $C$. virginica had the highest $\delta^{15} \mathrm{~N}$ values compared to other detritivores and herbivores and was similar isotopically to plankton. One study involving the Pacific oyster $C$. gigas determined its dietary food sources to be macroalgae, $\mathrm{C}_{4}$ plants such as Spartina sp., benthic diatoms, and suspended POM, with approximately $30 \%$ of the diet coming from benthic diatoms and 20 to $60 \%$ from marine POM depending on the time of year (Decottignies et al. 2007). Using a mixing model, Dubois et al. (2007) found that C. gigas consumed 4 different food sources (terrestrial organic matter, microphytobenthos, Ulva, and marine POM) in different quantities at different sites depending on which food source was available.

\section{Trophic dynamics - fishes}

The sheepshead Archosargus probatocephalus did not acquire any carbon from oysters (Tables $2 \& 3$, Figs. 2 \& 3) even though it is known to feed on them (Jennings 1985). Sheepshead are omnivores and can feed on worms, amphipods, shrimp, plant matter, crabs, small fishes, bivalves, and gastropods (Overstreet \& Heard 1982, Jennings 1985, Cutwa \& Turingan 2000, Lenihan et al. 2001). In the current study, this species mainly consumed crabs and shrimps and possibly other smaller fishes found on the reef (Tables 2 \& 3, Figs. 2 \& 3). Since smaller individuals of this species were present in the net and samples $(3.1$ to $6.1 \mathrm{~cm})$, lack of oysters in the diet of this fish (based on carbon signature) may be due to the smaller size and thus may be a sampling bias.

Other abundant fishes found on the study reefs were gulf toadfish Opsanus beta, code goby Gobiosoma robustum, crested goby Lophogobius cyprinoides, and skilletfish Gobiesox strumosus. Toadfish, in general, are known to feed on mud crabs (Grabowski 2004). In the current study, the food sources of toadfish were shrimp and crabs (Tables $2 \& 3$, Figs. 2 \& 3). Gobiosoma spp. are known to feed on small invertebrates such as shrimp, amphipods, and worms (Breitburg 1999) and their food source in the current study was mainly comprised of worms (Tables $2 \& 3$, Figs. $2 \& 3$ ). The crested goby is an opportunistic feeder that feeds on algae, detritus, amphipods, isopods, copepods, polychaetes, mollusks, bivalves, small crabs, and barnacles (Darcy 1981, Yeager \&6 Layman 2011). They have been found to be an important link of sestonic production to higher trophic levels (Yeager \& Layman 2011). Its main food sources in the current study were benthic microalgae, worms, crabs, shrimp, and sinking POM (Table 3, Fig. 3). The skilletfish food sources were benthic microalgae, worms, and sinking POM (Table 3, Fig. 3).

Oyster reefs provide high densities of prey items, such as polychaetes, mollusks, and crustaceans, for resident predators, juvenile fishes, and adult transient fishes. This is especially the case for restored reefs when placed in areas such as mudflats where no shelter existed previously (Grabowski et al. 2005). Juveniles of several transient fishes were collected during the current study: pigfish Orthopristis chrysoptera, gray snapper Lutjanus griseus, lane snapper Lutjanus synagris, and lined sole Achirus lineatus. Juvenile pigfish are known to consume copepods, amphipods, polychaetes, shrimp, and other benthic invertebrates and are found on shallow flats with plant growth during the spring and early summer (Sutter \& McIlwain 1987, Lenihan et al. 2001). The single pigfish collected in the current study could have been consuming crabs and worms found on the oyster reef based on its stable carbon isotope value (Table 2, Fig. 2), but because it is not a resident species it could have been feeding elsewhere as well. Snappers feed on a variety of organisms, including amphipods, shrimps, crabs, and fishes, and are found inshore near grass beds or soft and sandy bottom areas (Bortone \& Williams 1986). Yeager \& Layman (2011) found that juvenile gray snapper fed almost entirely on oyster reef-associated prey items such as crabs, shrimp and fish, while subadults fed on both oyster reef- and mangrove-associated prey. Based on isotope values, they were likely consuming smaller fishes, crabs, and shrimps found on oyster reefs (Table 2, Fig. 2), depending on previous feeding areas. The lined sole feeds on worms, crustaceans, and small fishes, but in this study its carbon isotope values point to benthic microalgae, suspended POM, and oysters as food sources on the reef (Table 2, Fig. 2). More than likely this fish was not feeding on the reef and was probably resting between traveling from one area to another when it was collected.

\section{Trophic dynamics - overall}

Resident decapod crustaceans and fishes found on oyster reefs in this study, in addition to feeding on oyster directly, seem to be using the oyster reef 
mainly as habitat and shelter while also feeding on other reef-resident organisms. Based on an analysis of oyster shell habitat use in southwest Florida, Tolley \& Volety (2005) proposed that most resident species used the reef for the structure and refuge that oysters provide. It should be cautioned that their study examined the habitat utilization by various resident decapods and fishes, but did not examine the trophodynamics within an oyster reef. Eurypanopeus depressus, Petrolisthes armatus, and Alpheus heterochaelis all use the spaces between oysters and in oyster shells themselves for shelter and to avoid desiccation and predation (Grant \& McDonald 1979, McDonald 1982, Williams 1984, Tolley \& Volety 2005, Van Horn \& Tolley 2009). Wasno et. al.

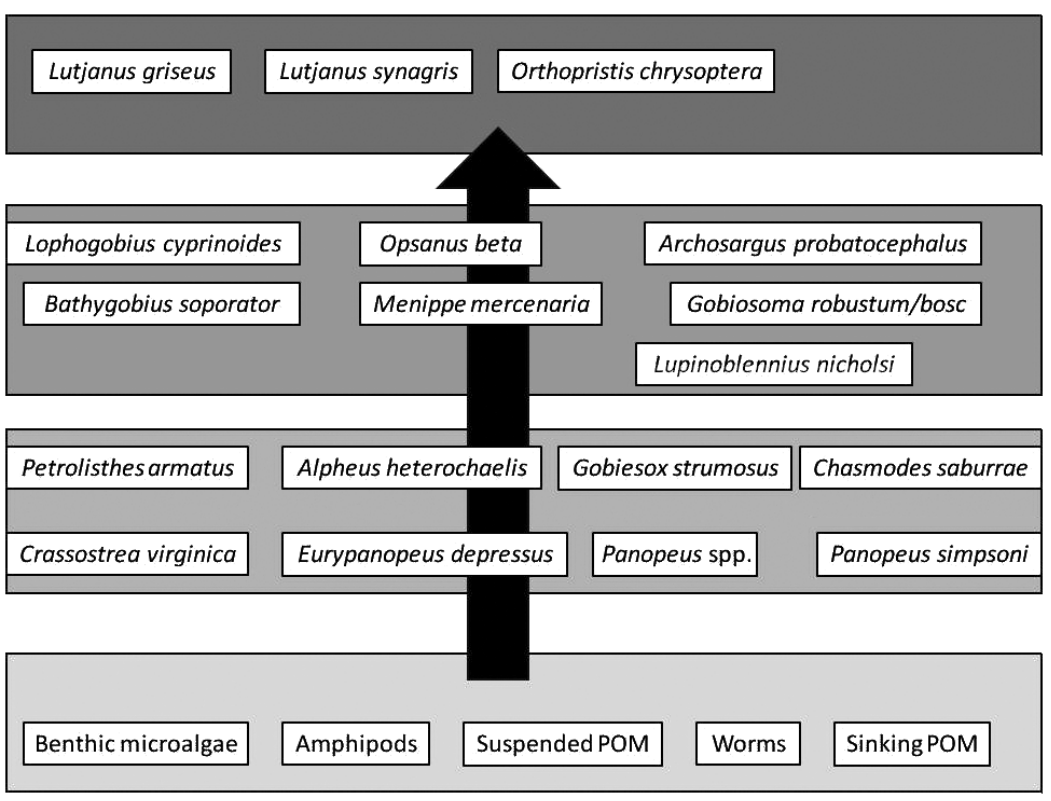

Fig. 9. Conceptual model of trophic relationships
(2009) found that these crab species are consumed by transient fish, and thus the carbon and biomass is transferred from within oyster reefs to higher trophic levels (Fig. 9). The results of that study demonstrated the ecological importance of oyster reefs in trophic transfer. Many resident fish species are known to attach their eggs to the insides of unfouled, articulated oyster shells, including the gobies Gobiosoma bosc, Gobiosoma robustum, and Bathygobius soporator, skilletfish Gobiesox strumosus, and Florida blenny Chasmodes saburrae (Peters 1981, 1983, Breitburg 1999). The oysters themselves provide the shelter, habitat, and food in the form of mucus-bound biodeposits (Newell 1988, 2004).

\section{Seasonal influences}

PCA revealed a couple of trends. First, Hendry/ Mullock Creeks samples showed differences in $\delta^{13} \mathrm{C}$ values during all sampling months, and Estero River samples showed the same trend; the 2 sites were also distinct from one another. Depending on tissue turnover rates, $\delta^{13} \mathrm{C}$ values will be biased towards the most recent feeding patterns (Michener \& Kaufman 2007). The average $\delta^{13} \mathrm{C}$ values for the sites suggested that carbon sources for these 2 systems must be different. Average Estero River values were between -21 and $-20 \%$, which is indicative of a phytoplankton carbon source (-21\%: Fry \& Sherr 1984). Average Hendry/Mullock Creeks values were between -25 and $-24 \%$, which is indicative of a ter- restrial $\mathrm{C}_{3}$ plant carbon source $(-23$ to $-30 \%$ : Fry \& Sherr 1984). Based on $\delta^{13} \mathrm{C}$ scores (Figs. 4 \& 5), Factor 1 seems to be driven by site. During the wet season, more water and nutrients are brought into the estuary due to the increase in rainfall. As the Hendry/ Mullock Creeks site had a higher flow rate from upstream sources, it received more runoff and nutrients from upland plants especially during the wet season (Fig. 8). This would explain the grouping of sites seen along Factor 1. The loadings indicated that these groupings are driven by the samples Sediment (Sed), Oyster, Alpheus, Eurypanopeus, Petrolisthes, and Opsanus depending on whether Sed was included in the analysis.

Second, $\delta^{15} \mathrm{~N}$ values indicated that samples collected at different times of the year were similar to one another. This is most likely due to seasonal changes in species composition on the reefs as well as increases in water temperature and spawning processes in the estuary that caused the trophic position of each species to change based on availability of food sources. Factor 1 seemed to be driven by water temperature increases and spawning processes occurring on the reef during May and September.

Temperature is an important factor that influences gonadal development and spawning in oysters (Shumway 1996, Thompson et al. 1996). In southwest Florida estuaries, oysters appear to continuously spawn between April/May and October (Volety 2008, Volety et al. 2009). Warm water temperatures and abundance of food seem to facilitate continuous 
reproductive activity in oysters from southwest Florida (Volety 2008).

Oysters are not the only organisms spawning on the reef. The number of ovigerous crabs and shrimp observed during the current study was much higher during May and September compared to November and February at the Estero River site (data not shown). The spawning season for grass shrimp is from March to October, with eggs hatching 12 to $60 \mathrm{~d}$ after fertilization, depending on species and geographical location (Anderson 1985). Ovigerous females of Eurypanopeus depressus and Panopeus spp. have been found from March through October with peak numbers occurring in late April to May and in September (McDonald 1982).

These changes in temperature and spawning processes for the organisms in this study influenced the differences seen between the sites, with Alpheus, Opsanus, and Oyster driving these differences based on the $\delta^{15} \mathrm{~N}$ loadings. The organisms used in the PCA all spawn and carry eggs during the same time period (April to October). This caused the trophic relationships within the community to change because organisms that were actively spawning or carrying eggs may not have been actively feeding or were avoiding predators. Also, as these juvenile organisms developed and grew in size there would be a shift in their diet that would alter their trophic relationships on the reef. The trophic dynamics on the reef seemed to change during different times of the year due to these changing processes.

Freshwater inflow influences the diversity and abundance of organisms found on oyster reefs. The abundance and diversity of organisms at the Hendry/ Mullock Creeks site were lower compared to the Estero River site, indicating that freshwater flow did have an influence. Also, the Hendry/Mullock Creeks samples showed a difference in carbon isotopic compositions compared to the Estero River samples, indicating that freshwater inflows influenced the carbon source and thus the quality of food at this site. Quality of food has an effect on the energetics of marine organisms, including oysters and oyster reef-resident organisms, and may have implications for reproduction, recruitment, and ultimately survival of these organisms in estuaries.

\section{SUMMARY}

This study provides additional evidence that as essential fish habitat, oyster reefs provide 3-dimensional structure, habitat, and shelter for many resi- dent species and food for resident and transient species. This study is also unique because multiple trophic levels in an oyster reef system were investigated simultaneously. Stable isotope analysis was used to determine trophic relationships within multiple levels of the community found on oyster reefs. Fig. 9 is a conceptual model of these trophic relationships. The organic matter sources, amphipods, and worms are at the lowest level and are consumed by oysters, resident crabs, shrimp, and fishes. The crabs and shrimp are then consumed by other resident crabs and fish species. Transient fish species such as Lutjanus spp. come to the reef to feed on the reefresident crab, shrimp, and fish species. The stable isotope signatures of the food sources for various organisms corroborated with previously reported gut content analysis and observed feeding behavior data.

Acknowledgements. The South Florida Water Management District provided grant funding to support this research within a larger project. Grant funding from the Explorers Club of Southwest Florida, the Marco Island Shell Club, and the Office of Research and Sponsored Programs was used to support stable isotope analysis of samples and travel to conferences. Field and laboratory support was provided by the Coastal Watershed Institute Marine Laboratory. Stable isotope analyses were performed at the University of California Davis Stable Isotope Facility.

\section{LITERATURE CITED}

Anderson G (1985) Species profiles: life histories and environmental requirements of coastal fishes and invertebrates (Gulf of Mexico) - grass shrimp. US Fish and Wildlife Service Biological Report 82(11.35) US Army Corps of Engineers, TR EL-82-4

Bortone SA, Williams JL (1986) Species profiles: life histories and environmental requirements of coastal fishes and invertebrates (South Florida) - gray, lane, mutton, and yellowtail snappers. US Fish and Wildlife Service Biological Report 82(11.52). US Army Corps of Engineers, TR EL-82-4

Boutton TW (1991) Stable carbon isotope ratios of natural materials: I. Sample preparation and mass spectrometric analysis In: Coleman DC, Fry B (eds) Carbon isotope techniques. Academic Press, San Diego, CA, p 155-171

Breitburg DL (1999) Are three-dimensional structure and healthy oyster populations the key to an ecologically interesting and important fish community? In: Luckenbach MW, Mann R, Wesson JA (eds) Oyster reef habitat restoration: a synopsis and synthesis of approaches. Virginia Institute of Marine Science Press, Gloucester Point, VA, p 239-250

Bucci JP, Showers WJ, Rebach S, DeMaster D, Genna B (2007) Stable isotope analyses $\left(\delta^{15} N\right.$ and $\left.\delta^{13} C\right)$ of the trophic relationships of Callinectes sapidus in two North Carolina estuaries. Est Coasts 30:1049-1059

Caine EA (1975) Feeding and masticatory structures of 
selected Anomura (Crustacea). J Exp Mar Biol Ecol 18: 277-301

Coen LD, Luckenbach MW, Breitburg DL (1999) The role of oyster reefs as essential fish habitat: A review of current knowledge and some new perspectives. Am Fish Soc Symp 22:438-454

Conkright ME, Sackett WM (1986) A stable carbon isotope evaluation of the contribution of terriginous carbon to the marine food web in Bayboro Harbor, Tampa Bay, Florida. Contrib Mar Sci 29:131-139

Crabtree RE, Dean JM (1982) The structure of two South Carolina estuarine tide pool fish assemblages. Estuaries 5:2-9

Cutwa MM, Turingan RG (2000) Intralocality variation in feeding biomechanics and prey use in Archosargus probatocephalus (Teleostei, Sparidae), with implications for the ecomorphology of fishes. Environ Biol Fishes 59: 191-198

Darcy GH (1981) Food habits of the crested goby, Lophogobius cyprinoides, in two Dade County, Florida, waterways. Bull Mar Sci 31:928-932

- Decottignies P, Beninger PG, Rincé Y, Riera P (2007) Trophic interactions between two introduced suspension-feeders, Crepidula fornicata and Crassostrea gigas, are influenced by seasonal effects and qualitative selection capacity. J Exp Mar Biol Ecol 342:231-241

> DeNiro MJ, Epstein S (1978) Influence of diet on the distribution of carbon isotopes in animals. Geochim Cosmochim Acta 42:495-506

DeNiro MJ, Epstein S (1981) Influence of diet on the distribution of nitrogen isotopes in animals. Geochim Cosmochim Acta 45:341-351

> Dubois S, Orvain F, Marin-Léal JC, Ropert M, Lefebvre S (2007) Small-scale spatial variability of food partitioning between cultivated oysters and associated suspensionfeeding species, as revealed by stable isotopes. Mar Ecol Prog Ser 336:151-160

Estero Bay Marine Laboratory (2004) Estero Bay Research Studies: 9th Annual Report Water Year 2003-2004

Florida Department of Natural Resources (1983) Estero Bay Aquatic Preserve Management Plan, Tallahasse, FL

Fry B, Sherr EB (1984) $\delta^{13} \mathrm{C}$ measurements as indicators of carbon flow in marine and freshwater ecosystems. Contrib Mar Sci 27:13-47

Fukumori K, Oi M, Doi H, Okuda N and others (2008) Food sources of the pearl oyster in coastal ecosystems of Japan: evidence from diet and stable isotope analysis. Estuar Coast Shelf Sci 76:704-709

Gearing JN (1991) The study of diet and trophic relationships through natural abundance ${ }^{13} \mathrm{C}$. In: Coleman DC, Fry B (eds) Carbon isotope techniques. Academic Press, San Diego, CA, p 201-218

> Grabowski JH (2004) Habitat complexity disrupts predatorprey interactions but not the trophic cascade on oyster reefs. Ecology 85:995-1004

Grabowski JH, Peterson CH (2007) Restoring oyster reefs to recover ecosystem services. In: Cuddington $\mathrm{K}$, Byers JE, Wilson WG, Hastings A (eds) Ecosystem engineers. Elsevier, Burlington, MA, p 281-298

> Grabowski JH, Hughes AR, Kimbro DL, Dolan MA (2005) How habitat setting influences restored oyster reef communities. Ecology 86:1926-1935

Grant J, McDonald J (1979) Desiccation tolerance of Eurypanopeus depressus (Smith) (Decapoda: Xanthidae) and the exploitation of microhabitat. Estuaries 2:172-177
Haines EB, Montague CL (1979) Food sources of estuarine invertebrates analyzed using ${ }^{13} \mathrm{C} /{ }^{12} \mathrm{C}$ ratios. Ecology 60 : 48-56

Harding JM, Mann R (2001) Oyster reefs as fish habitat: opportunistic use of restored reefs by transient fishes. J Shellfish Res 20:951-959

Hazlett BA (1962) Aspects of the biology of snapping shrimp (Alpheus and Synalpheus). Crustacaceana 4:82-83

Herberholz J, Schmitz B (1998) Role of mechanosensory stimuli in intraspecific agonistic encounters of the snapping shrimp (Alpheus heterochaelis). Biol Bull 195: $156-167$

> Hughes AR, Grabowski JH (2006) Habitat context influences predator interference interactions and the strength of resource partitioning. Oecologia 149:256-264

Jennings CA (1985) Species profiles: life histories and environmental requirements of coastal fishes and invertebrates (Gulf of Mexico) - sheepshead. US Fish and Wildlife Service Biological Report 82(11.29). US Army Corps of Engineers, TR EL-82-4

Lenihan HS, Peterson CH, Byers JE, Grabowski JH, Thayer GW, Colby DR (2001) Cascading of habitat degradation: oyster reefs invaded by refugee fishes escaping stress. Ecol Appl 11:764-782

> Loh AN, Bauer JE, Canuel EA (2006) Dissolved and particulate organic matter source-age characterization in the upper and lower Chesapeake Bay: a combined isotope and biochemical approach. Limnol Oceanogr 51: 1421-1431

Luckenbach MW, Coen LD, Ross PG Jr, Stephen JA (2005) Oyster reef habitat restoration: relationships between oyster abundance and community development based on two studies in Virginia and South Carolina. J Coast Res 40(Spec Issue):64-78

McDermott J (1960) The predation of oysters and barnacles by crabs of the family Xanthidae. Proc Pennsylvania Acad Sci 34:199-211

McDonald J (1982) Divergent life history patterns in the cooccurring intertidal crabs Panopeus herbstii and Eurypanopeus depressus (Crustacea: Brachyura: Xanthidae). Mar Ecol Prog Ser 8:173-180

Menzel RW, Hopkins SH (1956) Crabs as predators of oysters in Louisiana. Proc Natl Shellfish Assoc 46:177-184

Michener RH, Kaufman L (2007) Stable isotope ratios as tracers in marine food webs: an update. In: Michener R, Lajtha K (eds) Stable isotopes in ecology and environmental science, 2nd edn. Blackwell Publishing, Malden, MA, p 238-282

Milke LM, Kennedy VS (2001) Mud crabs (Xanthidae) in Chesapeake Bay: claw characteristics and predation on epifaunal bivalves. Invertebr Biol 120:67-77

Minagawa M, Wada E (1984) Stepwise enrichment of ${ }^{15} \mathrm{~N}$ along food chains: Further evidence and the relation between $\delta^{15} \mathrm{~N}$ and animal age. Geochim Cosmochim Acta 48:1135-1140

Newell RIE (1988) Ecological changes in Chesapeake Bay: are they the result of overharvesting the American oyster, Crassostrea virginica? In: Lynch MP, Krome EC (eds) Understanding the estuary: advances in Chesapeake Bay research. Chesapeake Research Consortium, Gloucester Point, VA, Publication 129 CBP/TRS 24/88, p 536-546

Newell RIE (2004) Ecosystem influences of natural and cultivated populations of suspension-feeding bivalve molluscs: a review. J Shellfish Res 23:51-61 
Nolan AN, Salmon M (1970) The behavior and ecology of snapping shrimp (Crustacea: Alpheus heterochaelis and Alpheus normanni). Forma Functio 2:289-335

Overstreet RM, Heard RW (1982) Food contents from six commercial fishes from Mississippi Sound. Gulf Res Rep 7:137-149

Peters KM (1981) Reproductive biology and development osteology of the Florida blenny, Chasmodes saburrae (Perciformes: Blenniidae). Northeast Gulf Sci 4:79-98

Peters KM (1983) Larval and early juvenile development of the frillfin goby, Bathygobius soporator (Perciformes: Gobiidae). Northeast Gulf Sci 6:137-153

Peterson BJ, Fry B (1987) Stable isotopes in ecosystem studies. Annu Rev Ecol Evol Syst 18:293-320

$>$ Peterson BJ, Howarth RW (1987) Sulfur, carbon, nitrogen isotopes used to trace organic matter flow in the saltmarsh estuaries of Sapelo Island, Georgia. Limnol Oceanogr 32:1195-1213

Posey MH, Alphin TD, Powell CM, Townsend E (1999) Use of oyster reefs as habitat for epibenthic fish and decapods. In: Luckenbach MW, Mann R, Wesson JA (eds) Oyster reef habitat restoration: a synopsis and synthesis of approaches. Virginia Institute of Marine Science, School of Marine Science, College of William and Mary, VIMS Press, p 229-237

Post DM (2002) Using stable isotopes to estimate trophic position: models, methods, and assumptions. Ecology 83: 703-718

Reames RC, Williams AB (1983) Mud crabs of the Panopeus herbstii H.M. Edw., s.l., complex in Alabama, U.S.A. Fish Bull 81:885-890

Riera P, Richard P (1996) Isotopic determination of food sources of Crassostrea gigas along a trophic gradient in the estuarine bay of Marennes-Oléron. Estuar Coast Shelf Sci 42:347-360

Shumway SE (1983) Oxygen consumption and salinity tolerance in four Brazilian crabs. Crustacaceana 44:76-82

Shumway SE 1996. Natural environmental factors. In: Kennedy VS, Newell RIE, Eble AF (eds). The Eastern Oyster Crassostrea virginica. Maryland Sea Grant College, University of Maryland System, College Park, MD, p 467-513

Sutter FC, McIlwain TD (1987) Species profiles: life histories and environmental requirements of coastal fishes and invertebrates (Gulf of Mexico) - pigfish. US Fish and

Editorial responsibility: Roger Hughes,

Bangor, UK
Wildlife Service Biological Report 82(11.71). US Army Corps of Engineers, TR EL-82-4

Thompson RJ, Newell RIE, Kennedy VS, Mann R 1996. Reproductive processes and early development. In: Kennedy VS, Newell RIE, Eble AF (eds) The eastern oyster Crassostrea virginica. Maryland Sea Grant College, University of Maryland System, College Park, MD, p 335-370

Tolley SG, Volety AK (2005) The role of oysters in habitat use of oyster reefs by resident fishes and decapod crustaceans. J Shellfish Res 24:1007-1012

Tolley SG, Volety AK, Savarese M (2005) Influence of salinity on the habitat use of oyster reefs in three southwest Florida estuaries. J Shellfish Res 24:127-137

Tolley SG, Volety AK, Savarese M, Walls LD, Linardich C, Everham EM III (2006) Impacts of salinity and freshwater inflow on oyster-reef communities in Southwest Florida. Aquat Living Resour 19:371-387

- Van Horn J, Tolley SG (2009) Acute response of the estuarine crab Eurypanopeus depressus to salinity and desiccation stress. J Crustac Biol 29:556-561

Volety AK (2008) Effects of salinity, heavy metals, and pesticides on health and physiology of oysters in the Caloosahatchee Estuary. Ecotoxicology 17:579-590

Volety AK, Savarese M, Tolley SG, Sime P, Goodman P, Doering P (2009) Eastern oysters (Crassostrea virginica) as an indicator for restoration of Everglades Ecosystems. Ecol Indic 9:S120-S136

Wasno RM, Volety AK, Doering PH, Crean D (2009) The importance of oyster reef community in the diet of predatory fish. Book of abstracts, Am Soc Limnol Oceanogr, Nice

Wells HW (1961) The fauna of oyster beds, with special reference to the salinity factor. Ecol Monogr 31:239-266

Wenner E, Beatty HR, Coen L (1996) A method for quantitatively sampling nekton on intertidal oyster reefs. J Shellfish Res 15:769-775

Williams AB (1984) Shrimps, lobsters, and crabs of the Atlantic coast of the Eastern United States, Maine to Florida. Smithsonian Institution Press, Washington, DC

> Yeager LA, Layman CA (2011) Energy flow to two abundant consumers in a subtropical oyster reef food web. Aquat Ecol 45:267-277

Zimmerman RJ, Minello TJ, Baumer TJ, Castiglione MC (1989) Oyster reef as habitat for estuarine macrofauna. NOAA Technical Memorandum, NMFS-SEFC-249

Submitted: February 10, 2012; Accepted: May 15, 2012 Proofs received from author(s): August 6, 2012 